Revista Brasileira de Cartografia

ISSN 1808-0936 | https://doi.org/10.14393/revbrascartogr

Sociedade Brasileira de Cartografia, Geodésia, Fotogrametria e Sensoriamento Remoto

\title{
Edaphoclimatic Zoning: Methodology and Application to Apple Cultivation in a Brazilian Watershed
}

\section{Zoneamento Edafoclimático: Metodologia e Aplicação no Cultivo da Maçã em uma Bacia Hidrográfica Brasileira}

Geise Macedo dos Santos ${ }^{1}$, Gisele Cemin ${ }^{2}$, Taison Anderson Bortolin ${ }^{3}$ e Vania Elisabete Schneider ${ }^{4}$

1 Universidade de Caxias do Sul, Instituto de Saneamento Ambiental, Caxias do Sul, Brasil. gmsantos5@ucs.br. ORCID: https://orcid.org/0000-0003-0471-7984

2 Universidade de Caxias do Sul, Instituto de Saneamento Ambiental, Caxias do Sul, Brasil. gcemin3@ucs.br. ORCID: https://orcid.org/0000-0003-1274-8000

3 Universidade de Caxias do Sul, Instituto de Saneamento Ambiental, Caxias do Sul, Brasil. tabortol@ucs.br. ORCID: https://orcid.org/0000-0003-0905-5684

4 Universidade de Caxias do Sul, Instituto de Saneamento Ambiental, Caxias do Sul, Brasil. veschnei@ucs.br. ORCID: https://orcid.org/0000-0001-8217-3607

Resumo: O planejamento do uso e ocupação do solo é indispensável quando se trata de buscar os melhores resultados tendo em vista a sustentabilidade socioeconômica e ambiental. Neste contexto, Sistemas de Informação Geográfica são ferramentas que permitem através do mapeamento identificar características físicas e climáticas visando o melhor resultado para um cultivo em particular o que caracteriza o zoneamento edafoclimático. Este artigo objetivou elaborar e aplicar uma metodologia para criar um zoneamento edafoclimático, focado no cultivo da maçã, tendo como unidade de estudo a bacia hidrográfica do rio Socorro, localizada no interior do município de Vacaria, Brasil. Foram considerados como parâmetros climáticos a demanda hídrica e o repouso hibernal e como parâmetros físicos a pedologia, áreas de preservação permanente, uso do solo e declividade, obtendo-se um mapa com a representação de áreas aptas e restritas. Os resultados apontaram cerca de $80 \%$ da bacia hidrográfica corresponde a áreas aptas para o cultivo de maçã. A metodologia proposta pode ser aplicada a outras regiões e outros cultivos subsidiando assim a tomada de decisão quanto ao uso e ocupação do solo, sensibilidades e potencialidades.

Palavras-chave: Demanda hídrica. Uso do solo. Bacia hidrográfica. Zoneamento ambiental.

\begin{abstract}
The planning of land use and occupation is essential when it comes to seeking the best results in view of socioeconomic and environmental sustainability. In this context, Geographic Information Systems are tools that allow, through mapping, to identify physical and climatic characteristics aiming at the best result for a particular crop, which characterizes the edaphoclimatic zoning. This article aimed to elaborate and apply a methodology to create an edaphoclimatic zoning, focused on apple cultivation, having as study unit, the hydrographic basin of the Socorro river, located in countryside of the municipality of Vacaria, Brazil. Water demand and winter rest were considered as climatic parameters and pedology, areas of permanent preservation, and land use and slope as physical parameters, obtaining a map with the representation of suitable and restricted areas. The results showed about $80 \%$ of the hydrographic basin corresponding to areas suitable for apple cultivation. The proposed methodology can be applied to other regions and other crops, thus supporting decision-making regarding land use and occupation, sensitivities and potenciality.
\end{abstract}

Keywords: Water demand. Land use. Hydrographic basin. Environmental zoning.

\section{INTRODUCTION}

In the current days, more than ever, planning the land use presents a crucial activity to achieve the best results to both economics aims and environment conservation. Seeking better exploitation of an agricultural area, the adoption of right area can determine the success or the failure of a project. Furthermore, the climatic 
conditions represent a determinant factor to the development of cultivation.

Using Geographic Information Systems (GIS), it is possible to map the most suitable areas for each use. These uses can be understood as anthropic modifications of the landscape, which usually comprehend urban areas, infrastructure, agriculture and livestock. One of the greatest advantages of GIS is the mapping of large areas in a short time.

Considering the apple cultivation as object of study, there are demands, such as water demand, climate demand and limitations, as topographic ones, which consists of conditioners to the introduction of this cultivation.

About the apple cultivation, in 2016 was produced approximately 79,000,000 tons of this fruit in the world, whose China's provided about $57 \%$ of total crop (FAOSTAT, 2018). In Brazil, the $13^{\circ}$ world producer, were counted in 2016 a crop of $1,069,336$ ton, equivalent to $1.35 \%$ of world's production. The state of Rio Grande do Sul, the leader grower in Brazil, contributed with 45.4\% of the Brazilian yield (IBGE, 2018; FEE, 2018). According to FEE (2018), Rio Grande do Sul has 15,592 hectares of apple plantation, of which, $76 \%$ are located in the northeast of the state. Besides that, the municipality of Vacaria, alone, concentrates 6,885 hectares of apple plantation, which represents $44 \%$ of the actual planted area in the state (FEE, 2018).

These statistics suggest that the municipality of Vacaria is a promising land when it comes to apple cultivation. Resuming the initial thoughts, the use of GIS is a tool to point, through mapping, the location of recommended areas to apple plantation, in order to maximize the chances of success.

Therefore, it is necessary the elaboration of a methodology to map the main demands and restrictions to apple cultivation, including climatic and physical environment parameters, which result is called Edaphoclimatic Zoning.

The idea of classifying an area into edaphoclimatic zones can be observed at Kurina et al. (2018) work. This example demonstrates that there are several methodologies and focus that can be used to generate an edaphoclimatic zoning. The adaptation and creation of different zoning are also possible. Although the edaphoclimatic zoning do not specifies a specific cultivation, instead, it indicates zones which similar characteristics. Those zones consider mostly soil composition, relief and temperature.

When it comes to a particular cultivation, such as teak wood, the needs of the plant are the main point to be examined. In his work, Guimarães (2012) evaluates the temperature, precipitation, water deficit and soil. Coelho, Dias and Finger (2016) adopt the same variables but using banana as the cultivation of interest. A similar methodology was applied for Silva (2017), focusing on rubber tree. It means that the variables considered on these works seem to be enough to identify suitable zones to each cultivation.

Another example used the sugarcane agro-environmental zoning, elaborated to the state of São Paulo, considers a slightly different focus and terminology. There are four classes (suitable, suitable with environmental limitations, suitable with environmental restrictions and unsuitable) and the zoning consider the vulnerability of the environment above sugarcane cultivation demands (JORDÃO; MORETTO, 2015). Those are examples of possibilities that could be applied to cultivation edaphoclimatic zoning.

Considering the numbers about apple growing in Brazil, it was elected a study area in the municipality of Vacaria, specifically a hydrographic basin, completely inserted in the municipality, the Socorro river watershed. Thus, this paper aimed to elaborate and apply a methodology to map the most suitable areas to apple cultivation in the study area.

\section{MATERIALS AND METHODS}

\subsection{Study area}

The study area (Figure 1) represents a watershed entirely inserted in the municipality of Vacaria, which involves a small percentage of urban area. The Socorro river watershed has $526.72 \mathrm{~km}^{2}$ and performs $25 \%$ of the municipality of Vacaria, known by his agricultural profile. This municipality is located at northeast region of the state of Rio Grande do Sul, the southernmost state of Brazil. 
Figure 1 - Location of Socorro river watershed (2018).

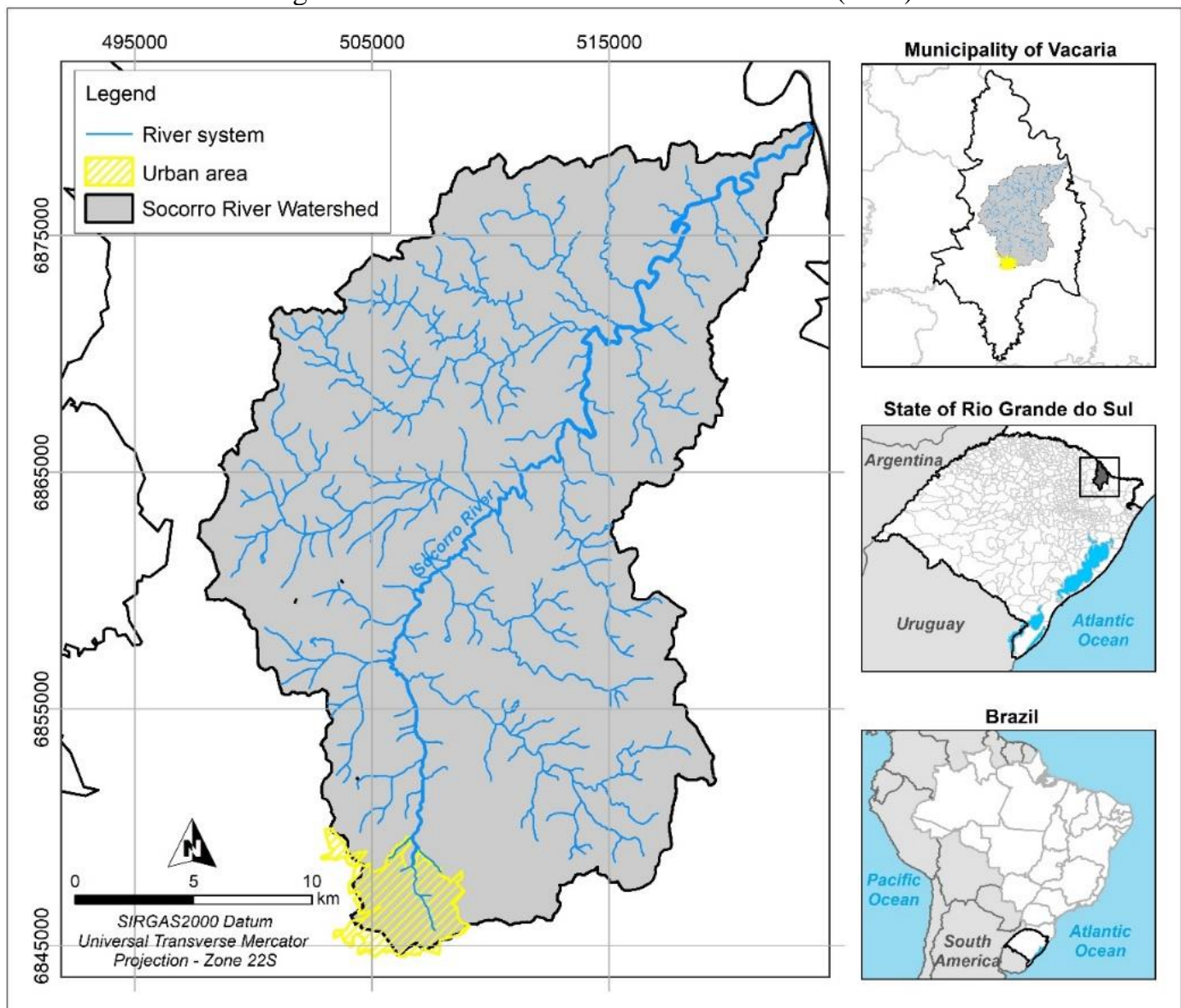

Source: The authors (2020).

\subsection{Methodology}

The elaboration of the edaphoclimatic map consisted in search for specialized information about apple cultivation, as well as data of study area physical characteristics. Among these characteristics, there are climate, pedology and topography of analyzed area.

According to Embrapa (1994), focusing on apple (Malus domestica, Bork) growing, to a full development cultivation requires temperate climate, which in the winter rest, means a temperature lesser than $7.2^{\circ} \mathrm{C}$. Varieties such as var. baigent, var. daiane, var. precocious fugi, var. mishima and var. pink lady, all present in the municipality of Vacaria, where the hydrographic basin is inserted, demands at least 650 accumulated hours of winter rest, in some cases, taking until 900 hours of desirable cold (FIORAVANÇO et al., 2011a, 2011b, 2012, 2013; FIORAVANÇO; CZERMAINSKI; OLIVEIRA, 2013). In order to verify the suitability of winter rest in Vacaria, it is necessary an analysis of literature.

Regarding the water demand, during the year, due both natural developments of the plant and climate conditions, such as temperature and air humidity, the water demand to apple plantation is variable. During elevated temperature periods, or plant/fruit growth, it is necessary farm irrigation. In the study accomplished by Fioravanço et al. (2010), the daily water demand calculated to Vacaria varies between 20,000L/hectare and $30,000 \mathrm{~L} / \mathrm{hectare}$. The evaluation of the aptitude of the study area depends on the water balance calculation, using rainfall data and real evapotranspiration acquired through National Institute of Meteorology (INMET).

Analyzing the pedology of the apple plantation, it is required soils at least 50 centimeters depths in order to root growing, and they also request good drainage. Preferably, high clay content soils and compacted superficial stratum have to be avoided. These characteristics damage the water infiltration and the root growth (EMBRAPA, 1994). Information regarding the different soil classes was extracted from Streck et al. (2008).

Besides the characteristics previously mentioned, it was considered land use restrictions to apple cultivation. It is forbidden the use of permanent preservation area (PPA) along the water resources and areas 
of restrict use, determined by Brazilian Federal Law n ${ }^{\circ} 12,561 / 2012$, modified by Brazilian Federal Law $\mathrm{n}^{\circ} 12,727 / 2012$, created based on hydrography and digital elevation model. In addition to land use and land cover maps, the urban area and the water resources classes were considered unsuitable to apple plantation. The Landsat satellite's OLI sensor image classification, with 30 meters of special resolution, was obtained through the supervised classification, using the Guaussian Maximum Likelihood algorithm pixel by pixel. To check the accuracy of the classification of satellite images the coefficient used was Kappa (LANDIS; KOCH, 1977), using as a reference the information collected in the field with the help of GNSS (Global Navigation Satellite System) and the satellite images. This coefficient is used to test the concordance between the observed results and those classified in an error matrix.

The slope map was generated based on the 1:50,000 cartographic information from Hasenack and Weber (2006). The level curves were interpolated using the triangular grid method (TIN) to create the digital elevation model (DEM). This map was used to generate the slope, which was reclassified into three classes: up to $25^{\circ}$, from $25^{\circ}$ to $45^{\circ}$ and more than $45^{\circ}$, the latter being considered a Permanent Preservation Area.

The maps were elaborate using the GIS software Idrisi Selva and ArcMap10, where the georeferenced data were disposed and manipulated in order to, through software tools, like buffer, slope and overlay, generate the final maps (Figure 2).

Figure 2 - Methodology of elaboration of the edaphoclimatic zoning for the apple crop.

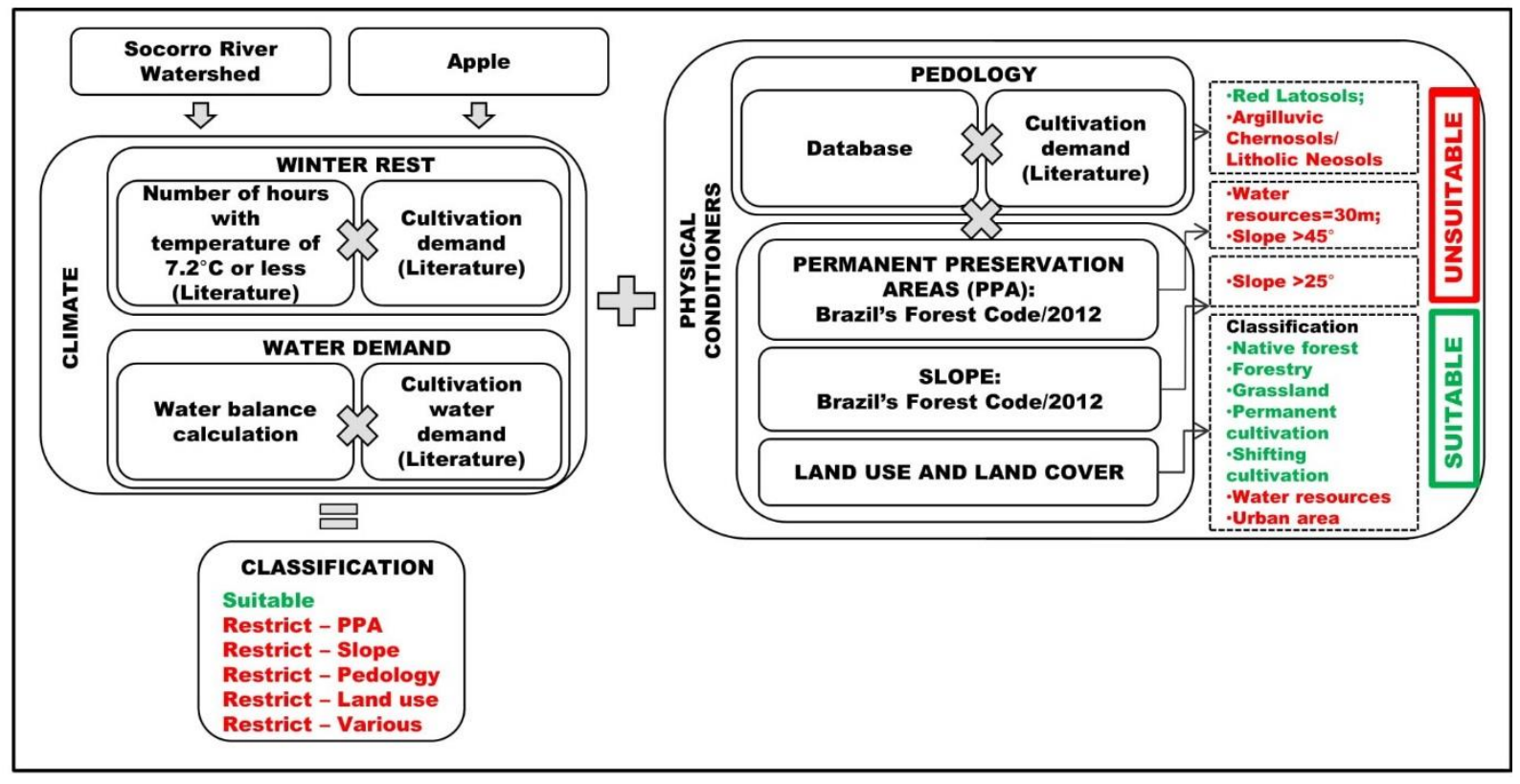

Source: The authors (2020).

\section{RESULTS AND DISCUSSIONS}

\subsection{Winter rest}

Some studies indicate that in Vacaria, the 2009/10 crop counted with 833 accumulated hours of cold, while during the 2011/12 crop, there was a decrease to 770 hours of cold. In the last harvest was measured 824 accumulated hours of cold. It means, when it is about temperature demand, the study area has high potential to apple cultivation (HAWERROTH; NACHTIGALL, 2016).

\subsection{Water demand}

The INMET data to Vacaria relative to 2017 were organized monthly, also converted in daily data (Table 1). We note that January, February and November, at least in 2017, did not response properly to daily water demand. On the other hand, in southern hemisphere, the initial months of the year correspond to harvest season. Moreover, the cumulated total of water per hectare is approximately $26,000 \mathrm{~L} / \mathrm{ha}$, which supplies the 
average water consumption in Vacaria that varies between $20,000 \mathrm{~L} /$ hectare and $30,000 \mathrm{~L} / \mathrm{hectare}$ (FIORAVANÇO et al., 2010). It means the water demand can be supplied, which does not represent an obstacle to apple plantation.

Table 1 - 2017 water balance to Socorro river watershed based on INMET data.

\begin{tabular}{l|c|c|c|c}
\hline \multicolumn{1}{c}{ Month } & $\begin{array}{c}\text { Average Rainfall } \\
(\mathbf{m m})\end{array}$ & $\begin{array}{c}\text { Real Evapotranspiration } \\
(\mathbf{m m})\end{array}$ & $\begin{array}{c}\text { Rainfall-Real } \\
\text { Evapotranspiration (mm) }\end{array}$ & $\begin{array}{c}\text { Daily water balance } \\
\text { per area (L/ha) }\end{array}$ \\
\hline January & 123.4 & 99.2 & 24.2 & 7,806 \\
\hline February & 108.6 & 79.8 & 28.8 & 10,286 \\
\hline March & 134.5 & 69.8 & 64.8 & 20,887 \\
\hline April & 140.9 & 63.0 & 77.9 & 25,967 \\
\hline May & 127.6 & 45.0 & 82.65 & 26,661 \\
\hline June & 165.0 & 42.0 & 123.0 & 41,000 \\
\hline July & 179.4 & 46.5 & 132.9 & 42,871 \\
\hline August & 129.0 & 55.8 & 73.2 & 23,613 \\
\hline September & 178.0 & 67.5 & 110.5 & 36,833 \\
\hline October & 210.1 & 80.6 & 129.5 & 41,774 \\
\hline November & 89.2 & 84.0 & 5.2 & 1,733 \\
\hline December & 189.6 & 99.2 & 90.4 & 29,161 \\
\hline
\end{tabular}

Source: The authors (2020).

\subsection{Pedology}

Between the two soils present in the study area (Figure 3a), the Red Latosols has the required characteristics to a proper apple cultivation, which occupies $95 \%\left(497.56 \mathrm{~km}^{2}\right)$ of the area (Table 2). The other areas, located nearby the watershed outfall, correspond to Argilluvic Chernosols and a small percentage of Litholic Neosols, which do not suit depths demand, drainage demand and clay content.

Table 2 - Pedology classification - apple cultivation suitability.

\begin{tabular}{l|c|c|c|c|c}
\hline \multirow{2}{*}{ Classification } & \multicolumn{2}{c}{ Area (classification) } & \multirow{2}{*}{ Suitability } & \multicolumn{2}{c}{ Area (suitability) } \\
\cline { 2 - 3 } & $\mathbf{k m}^{\mathbf{2}}$ & $\mathbf{\%}$ & & $\mathbf{k m}^{\mathbf{2}}$ & $\mathbf{\%}$ \\
\hline Red Latosols & 497.56 & 94.46 & Suitable & 497.56 & 94.46 \\
\hline Argilluvic Chernosols/Litholic Neosols & 29.16 & 5.54 & Unsuitable & 29.16 & 5.54 \\
\hline Entire watershed area & 526.72 & - & - & - & - \\
\hline
\end{tabular}

Source: The authors (2020). 
Figure 3 - Socorro river watershed suitable and unsuitable areas.
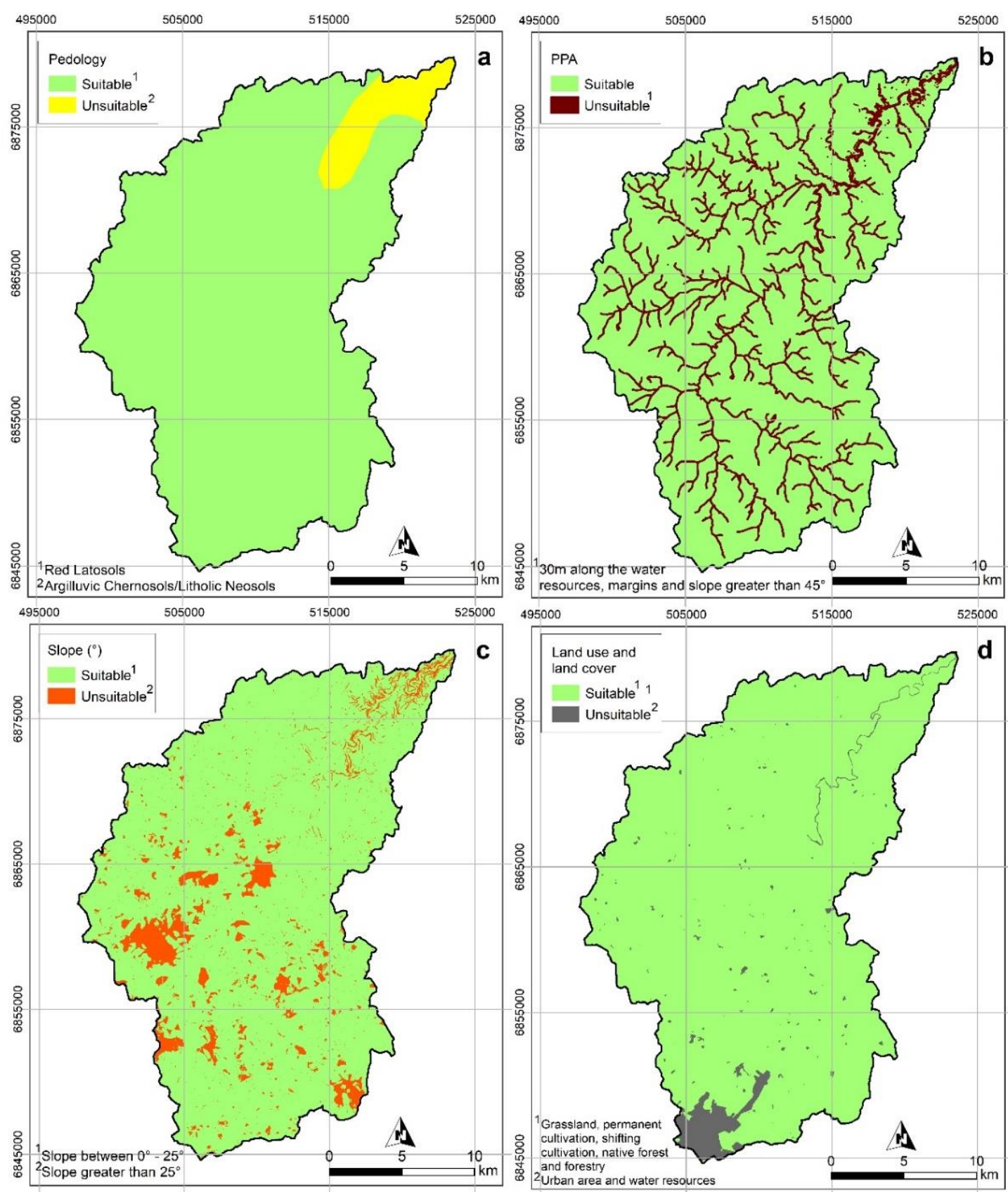

Source: The authors (2020).

\subsection{Permanent preservation area}

The permanent preservation areas (Figure 3b) delimited from the Brazilian Forest Code established in Law ${ }^{\circ} 12651 / 12 \mathrm{n}^{\circ} 12,651 / 12$ modified by Brazilian Federal Law n ${ }^{\circ} 12,727 / 12$, occupy $30.69 \mathrm{~km}^{2}$, just over $5 \%$ of the basin area (Table 3). These areas correspond to a strip of 30 meters on both sides of the watercourses existing in the basin, in addition to the areas where the slope is greater than $45^{\circ}$

Table 3 - Permanent preservation area - apple cultivation suitability.

\begin{tabular}{l|c|c|c}
\hline \multirow{2}{*}{ Classification } & \multicolumn{2}{|c}{ Area (classification) } & \multirow{2}{*}{ Suitability } \\
\cline { 2 - 3 } & $\mathbf{k m}^{2}$ & $\mathbf{\%}$ & \multirow{2}{*}{ Unsuitable } \\
\hline Slope & 30.50 & 5.79 & - \\
\hline Water resources & 0.19 & 0.04 & - \\
\hline Total area & 30.69 & 5.83 & \multirow{2}{*}{} \\
\hline
\end{tabular}

Source: The authors (2020). 


\subsection{Restricted use area}

Based on digital elevation model (DEM) of the area and the Brazil's Forest Code, the areas where the slope were superior than $25^{\circ}$ were identified (Figure 3c) in order to restrain the use of these areas to permanent cultivation. As result, $9 \%\left(47.78 \mathrm{~km}^{2}\right)$ of the study area were classified unsuitable to apple cultivation (Table 4).

Table 4 - Slope - apple cultivation suitability.

\begin{tabular}{l|c|c|c|c|c}
\hline \multirow{2}{*}{ Classification } & \multicolumn{2}{|c|}{ Area (classification) } & \multirow{2}{*}{ Suitability } & \multicolumn{2}{c}{ Area (suitability) } \\
\cline { 2 - 3 } \cline { 5 - 6 } & $\mathbf{k m}^{\mathbf{2}}$ & $\boldsymbol{\%}$ & & $\mathbf{k m}^{\mathbf{2}}$ & \% \\
\hline $0-25^{\circ}$ & 478.94 & 90.93 & Suitable & 478.94 & 90.93 \\
\hline$>25^{\circ}$ & 47.78 & 9.07 & Unsuitable & 47.78 & 9.07 \\
\hline Entire watershed area & 526.72 & - & - & - & - \\
\hline
\end{tabular}

Source: The authors (2020).

\subsection{Land use and land cover}

The land use and land cover map of the study area (Figure 4). According to the Kappa coefficient (LANDIS; KOCH,1977), the classification of the satellite image can be considered excellent, with an accuracy of $88 \%$. There is the presence of native forest at the region nearby the outfall. Beside there are strips of forest following a portion of the water courses that totalize $149.22 \mathrm{~km}^{2}(28.33 \%)$. The grasslands can be found over the watershed $\left(95.02 \mathrm{~km}^{2}, 18.04 \%\right)$, which create mosaic with anthropic classes, as shifting cultivation (233.7 $\left.\mathrm{km}^{2} ; 44.38 \%\right)$ and permanent cultivation $\left(24.85 \mathrm{~km}^{2} ; 4.72 \%\right)$. At the furthermost southern region detaches the urban area of Vacaria, which occupies $13.62 \mathrm{~km}^{2}$ (2,59\%). Forestry areas (Pinus sp.) and water resources (artificial rivers and lakes), with less expressive areas, can be observed in Table 5.

Figure 4 - Socorro river watershed land use and land cover.

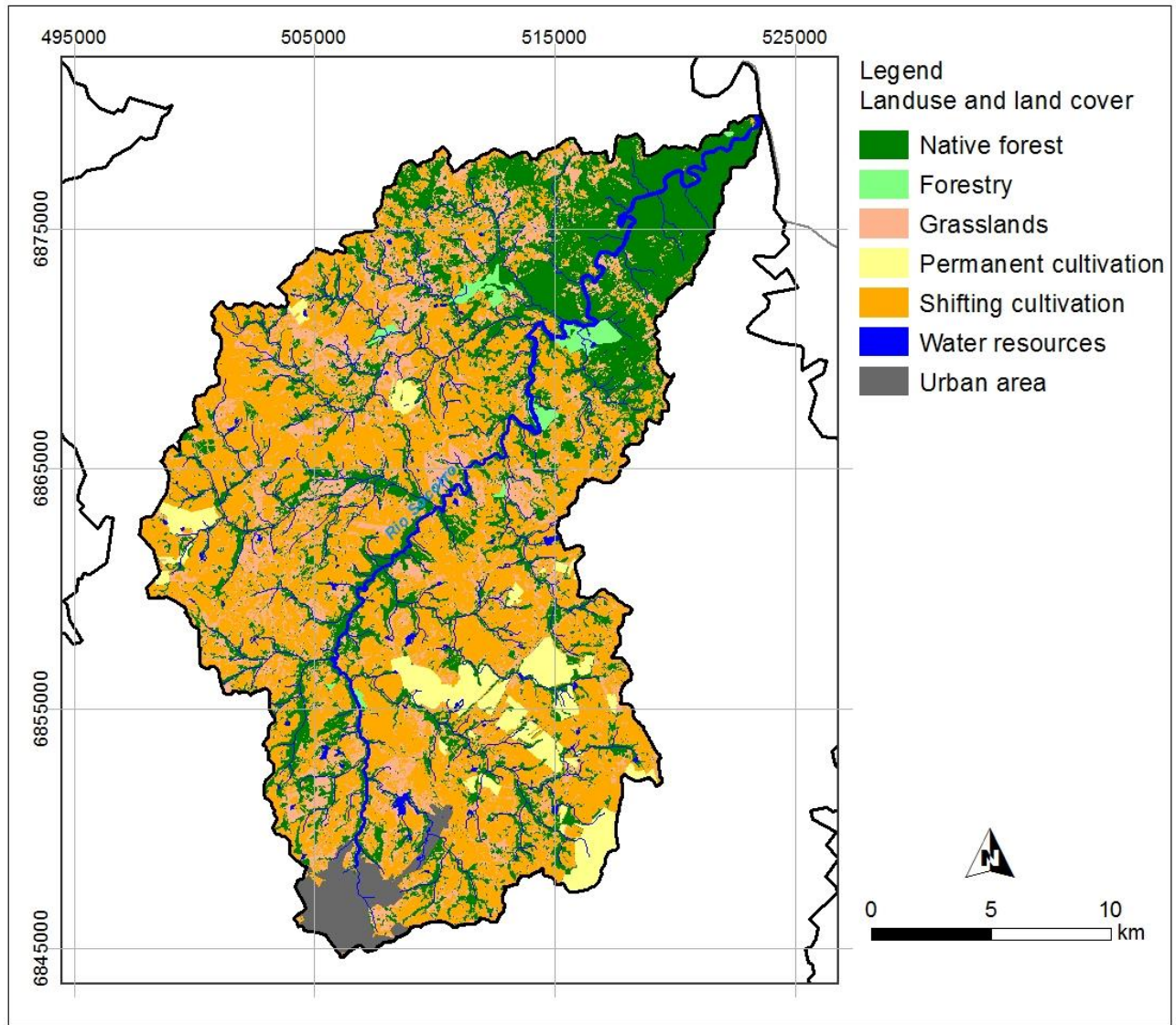

Source: The authors (2020). 
Considering the urban area class as a consolidated use, it was decided to classify this area as unsuitable to apple plantation. Analogously, the areas correspondent to water resources cannot be used apple cultivation. Over the remaining classes, were not applied use restrictions (Figure 3d). Thus, $96.53 \%\left(508.45 \mathrm{~km}^{2}\right)$ of the watershed area were classified as suitable to apple plantation, considering the land use and land cover (Table $5)$.

Table 5 - Land use and land cover - apple cultivation suitability.

\begin{tabular}{|c|c|c|c|c|c|}
\hline \multirow{2}{*}{ Classification } & \multicolumn{2}{|c|}{ Area (classification) } & \multirow{2}{*}{ Suitability } & \multicolumn{2}{|c|}{ Area (suitability) } \\
\hline & $\mathbf{k m}^{2}$ & $\%$ & & $\mathbf{k m}^{2}$ & $\%$ \\
\hline Native forest & 149.22 & 28.33 & \multirow{5}{*}{ Suitable } & \multirow{5}{*}{508.45} & \multirow{5}{*}{96.53} \\
\hline Forestry & 5.59 & 1.06 & & & \\
\hline Grassland & 95.02 & 18.04 & & & \\
\hline Permanent cultivation & 24.85 & 4.72 & & & \\
\hline Shifting cultivation & 233.77 & 44.38 & & & \\
\hline Water resources & 4.65 & 0.88 & \multirow{2}{*}{ Unsuitable } & \multirow{2}{*}{18.27} & \multirow{2}{*}{3.47} \\
\hline Urban area & 13.62 & 2.59 & & & \\
\hline Entire watershed area & 526.72 & - & - & - & - \\
\hline
\end{tabular}

Source: The authors (2020).

\subsection{Edafoclimatic zoning}

The edaphoclimatic zoning map (Figure 5) to the Socorro river watershed shows that there are no climatic restrictions in the area, both related to water demand and winter rest as well. Therefore, the unsuitable area to apple plantation correspond basically to physical restrictions imposed by pedology, consolidated land use and current environmental legislation (Brazilian Federal Low $n^{\circ} 12,651 / 12$ modified by Brazilian Federal Law $\left.n^{\circ} 12,727 / 12\right)$.

These restrictions are all over the watershed, specifically when it comes to PPAs, which follow the whole water courses and, even so, occupy lesser than $5 \%\left(24.39 \mathrm{~km}^{2}\right)$ of the study area. Among the classes which produce restrictions to the apple plantation, the biggest percentage responses to slope $\left(39.44 \mathrm{~km}^{2}\right.$, $7.49 \%$ ), located principally at the central portion of the watershed. The land use restriction, which contemplated the urban area and water resources, represents $2.93 \%\left(15.46 \mathrm{~km}^{2}\right)$ of the watershed, located mostly at the southern portion of the watershed. About restriction class related to pedology, the Argilluvic Chernosols and Litholic Neosols take place in $21.61 \mathrm{~km}^{2}(4.10 \%)$, close to the watershed outfall. The restriction class called "various" involves the areas where more than one restriction class takes place, which represents $12.02 \mathrm{~km}^{2}(2.28 \%)$ of study area. Ultimately, the areas classified as suitable to apple cultivation compose $413.78 \mathrm{~km}^{2}(78.56 \%)$, over the entire watershed as can be seen in Table 6 .

Table 6 - Edaphoclimatic classification.

\begin{tabular}{c|c|c}
\hline \multirow{2}{*}{ Classification } & \multicolumn{2}{|c}{ Area } \\
\cline { 2 - 3 } & $\mathbf{k m}^{\mathbf{2}}$ & $\mathbf{\%}$ \\
\hline Suitable & 413.78 & 78.56 \\
\hline Restrict - PPA & 24.39 & 7.63 \\
\hline Restrict - Slope & 39.44 & 2.93 \\
\hline Restrict - Land use & 15.46 & 4.10 \\
\hline Restrict - Pedology & 21.61 & 2.28 \\
\hline Restrict - Various & 12.02 & 100.00 \\
\hline Entire watershed area & 526.69 & \multicolumn{2}{|c}{} \\
\hline
\end{tabular}

Source: The authors (2020). 
Figure 5 - Apple cultivation edaphoclimatic map.

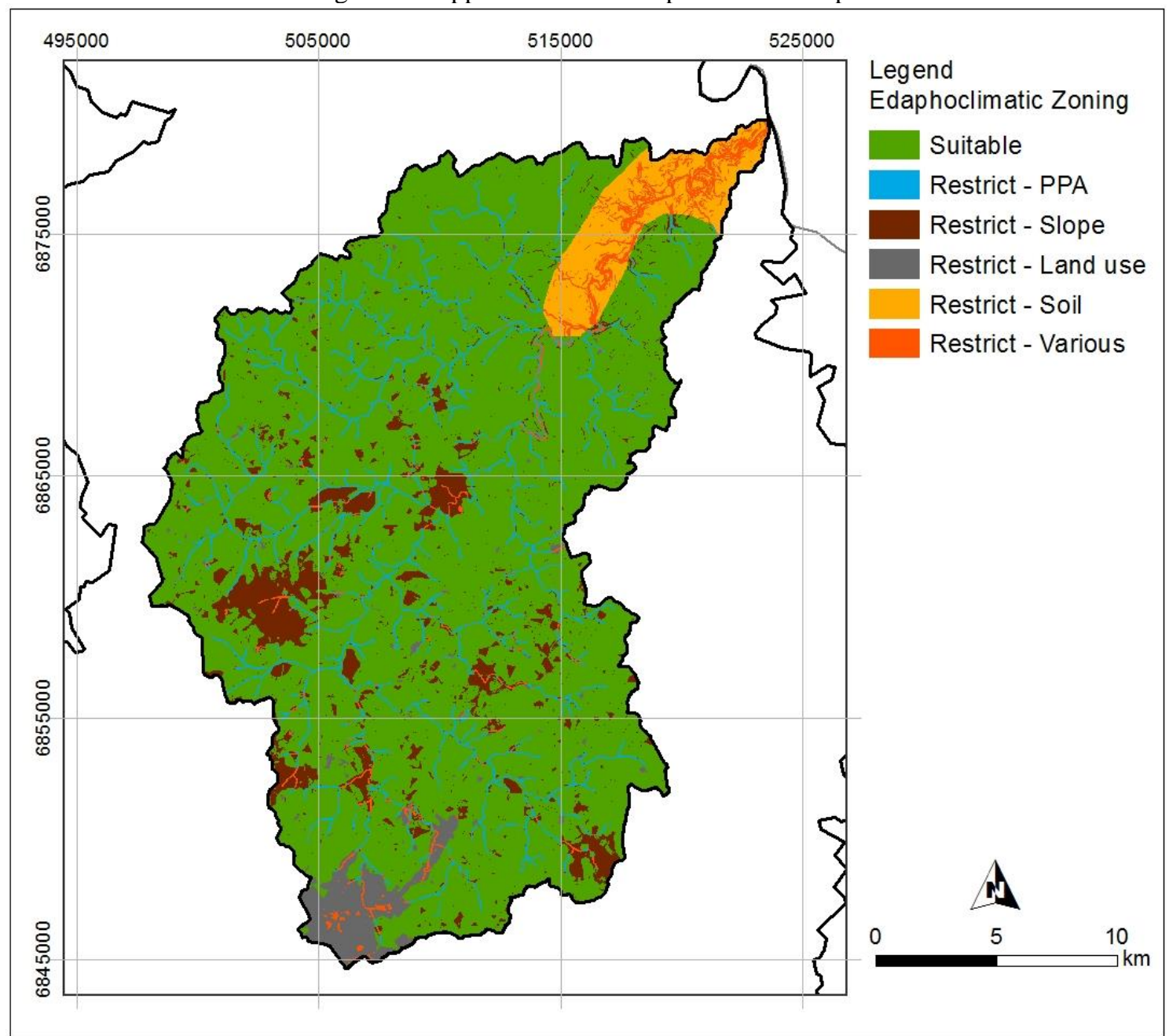

Source: The authors (2020).

The methodology used by Coelho, Dias and Finger (2016) applied to banana cultivation, has similar classes considers the altitude and the water deficiency. It concludes that the cultivation is only possible through irrigation. Although this work considers the annual average amount of water availability, it is distinguished that during summer there are need of irrigation, using the excess water from the rest of the year.

Kurina et al. (2018) also includes weights of importance to its parameters. At this work, there were not considered weights due its parameters nature, that only allows the suitable and unsuitable separation. A different approach was taken by Guimarães (2012), resulting in a continuous range between suitable and unsuitable, which makes difficult to identify the restriction relates to a specific area.

Jordão and Moretto (2015) considered air, soil and water quality, diversity of species, amongst other environmental parameters. As this zoning focus on the cultivation needs, the native forest and grasslands areas were not considered as unsuitable, however it is advised the use of anthropic areas, instead natural cover areas.

The susceptibility to leaf plague in rubber trees were a limiting condition to the edaphoclimatic zoning elaborated by Silva (2017). The environmental conditions that favors the development of this disease were treated as restrict. The susceptibility to diseases were not considered in this work, for there are several diseases that could attack the apple cultivation and the mechanism of action are difficult to map.

\section{CONCLUSIONS}

The edaphoclimatic zoning constitutes an effective and easy tool planning the landscape. Through mapping it is possible to identify the most suitable areas to different growing, which means basically this methodology can be applied in various cultivations and diverse environments. 
At Socorro river watershed, the climate conditions do not contribute effectively as restraining parameter, so the whole watershed was classified as suitable. Anyway, there are almost $80 \%$ of the watershed areas suitable to apple plantation, considering climate and physical conditions.

The suggestion to upcoming works is the appliance of this methodology in larger areas, such as the whole municipality or a group of municipalities. It could reveal a different behavior of climate parameters and other percentage distribution to physical classes. It also suggested the application of this tool to other cultivations, which would enable the union of various maps generating a complete guide to plantation.

\section{Acknowledgment}

This work was supported by the FAPERGS - Foundation of Research Support in the State of Rio Grande do Sul under Grant 16/2551-0000385-8 and SDECT - Secretariat for Economic Development, Science and Technology under Grant n. 1943-16.00/15-6 and CNPQ - National Council for Scientific and Technological Development (Conselho Nacional de Desenvolvimento Científico e Tecnológico) under Grant n. 311937/2018-7

\section{Authors' contribution}

The authors contributed to the elaboration of this work differently. The Eng. Geise Macedo dos Santos contributed to the data curation, the formal analysis, the investigation and methodology of the paper. Also participated the elaboration of the visualization and the writing.

Dra. Gisele Cemin was involved in the conceptualization, the formal analysis, the development of the methodology and the writing of the work.

Similarly, Dr. Taison Anderson Bortolin worked at the conceptualization of this work. The validation of the work and the writing also had his participation and supervision.

Dra. Vania Elisabete Schneider acted in the conceptualization of the project, its funding acquisition, posteriorly at the project administration. The author also participated the writing and supervision of this work.

\section{Conflict of Interest}

The authors declare no conflict of interest.

\section{References}

BRAZIL. Federal Low n ${ }^{\circ}$ 2,561 from May 25th, 2012 (2012) Decrees on the protection of native vegetation. Official Journal of the Union, Brasília, DF, May 25th, 2012, Section 1, p. 1.

BRAZIL. Federal Low $n^{\circ} 12,727$ from October 17th, 2012 (2012) Alters the Federal Low ${ }^{\circ} 12,561 / 12$. Official Journal of the Union, Brasília, DF, Oct. 17th, 2012, Section 1, p. 1.

COELHO, G. O.; DIAS, L. A. S.; FINGER, F. L. Agro-climatic zoning to banana-growing in the mesoregion of Vale do Rio Doce. Revista Brasileira de Fruticultura, Jaboticabal, v. 38, n. 4, p.1-14, 2016. https://doi.org/10.1590/0100-29452016908.

EMPRESA BRASILEIRA DE PESQUISA AGROPECUÁRIA (EMBRAPA). A cultura da maçã. Coleção Plantar, 19. Brasília: EMBRAPA-SPI, 1994. 107p.

FIORAVANÇO, J. C.; ALMEIDA, G. K.; CZERMAINSKI, A. B. C.; OLIVEIRA, P. R. D. Avaliação da Cultivar de Macieira Pink Lady em Vacaria, RS. Bento Gonçalves - RS: Embrapa Uva e Vinho, 2011. 8p. Comunicado Técnico.

FIORAVANÇO, J. C.; CZERMAINSKI, A. B. C.; ALVES, S. A. M.; NACHTIGALL, G. R. Condições Meteorológicas e sua Influência na Safra de Maçã 2009/10 na Região de Vacaria, RS. Bento Gonçalves - RS: Embrapa Uva e Vinho, 2010. 8p. Comunicado Técnico. 
FIORAVANÇO, J. C.; CZERMAINSKI, A. B. C.; BONETI, J. I. S.; NUNES, E. C.; PEREIRA, A. J.; Oliveira, P. R. D. Avaliação da Cultivar de Macieira Fuji Precoce em Vacaria, RS. Bento Gonçalves - RS: Embrapa Uva e Vinho, 2013. 8p. Comunicado Técnico.

FIORAVANÇO, J. C.; CZERMAINSKI, A. B. C.; OLIVEIRA, P. R. D. Avaliação da Cultivar de Macieira Baigent (Brookfield®) em Vacaria, RS. Bento Gonçalves - RS: Embrapa Uva e Vinho, 2013. 8p. Comunicado Técnico.

FIORAVANÇO, J. C.; CZERMAINSKI, A. B. C.; PEREIRA, A. J.; OLIVEIRA, P. R. D. Avaliação da cultivar de macieira Mishima em Vacaria, RS. Bento Gonçalves - RS: Embrapa Uva e Vinho, 2012. 8p. Comunicado Técnico.

FIORAVANÇO, J. C.; DENARDI, F.; CZERMAINSKI, A. B. C.; KVITSCHAL, M. V.; OLIVEIRA, P. R. D. Avaliação da Cultivar de Macieira Daiane em Vacaria, RS. Bento Gonçalves - RS: Embrapa Uva e Vinho, 2011. 8p. Comunicado Técnico.

FOOD AND AGRICULTURE ORGANIZATION OF THE UNITED NATIONS (FAOSTAT). FAOSTAT Data. Available in: 〈http://www.fao.org/faostat/en/\#data/QC〉. Accessed 28 Jan. 2018.

FUNDAÇÃO DE ECONOMIA E ESTATÍSTICA (FEE). FEE Data. Available in: http://feedados.fee.tche.br/feedados/. Accessed 31 Jan. 2018.

GuimarãeS, M. A. P. Cultivo de Tectona grandis L.f. no estado do Espírito Santo. 2012. 81 p. Dissertação (Programa de Pós-Graduação em Ciências Florestais) - Universidade Federal do Espírito Santo, Espírito Santo, 2012.

HASENACK, H.; WEBER, E. Base cartográfica vetorial contínua do Rio Grande do Sul na escala 1:50.000. Porto Alegre, RS: UFRGS IB Centro de Ecologia, 2010. 1:50.000.

HAWERROTH, F. J.; NACHTIGALL, G. R. Condições meteorológicas de outono e inverno e suas influências na safra de maçã 2016/17 na região de Vacaria, RS. Bento Gonçalves - RS: Embrapa Uva e Vinho, 2016. 8p. Comunicado Técnico.

INSTITUTO BRASILEIRO DE GEOGRAFIA E ESTATÍSTICA (IBGE). Systematic Survey of Agricultural Production. Available in: <https://sidra.ibge.gov.br/pesquisa/lspa/tabelas>. Accessed 31 Jan. 2018.

JORDÃO, C. O.; MORETTO, E. M. The environmental vulnerability and the territorial planning of the sugarcane cultivation. Ambiente \& Sociedade, São Paulo, v. 43, n. 1 p. 75-92, 2015. DOI. 10.1590/18094422ASOC675V1812015en.

KURINA, F. G.; SUSANA HANGB, S.; CORDOBA, M. A.; NEGROB, G. J.; BALZARINIA, M. G. Enhancing edaphoclimatic zoning by adding multivariate spatial statistics to regional data. Geoderma, v. 310, p. 170-177, 2018. DOI. 10.1016/j.geoderma.2017.09.011.

LANDIS, J.R.; KOCH, G.G. The measurement of observer agreement for categorical data. Biometrics, v. 33, n. 1, p. 159-174, 1977.

SILVA, D. C. Zoneamento edafoclimático da seringueira no município de Governador Valadares - MG. 2017. 67 p. Monografia (Especialização em Geoprocessamento) - Universidade Federal de Minas Gerais, Minas Gerais, 2017.

STRECK, E.V.; KAMPF, N.; DALMOLIN, R.S.D; KLAMT, E.; NASCIMENTO, P. C. do; SCHNEIDER, P.; GIASSON, E.; PINTO, L. F. S. Solos do Rio Grande do Sul. 2 ed. Porto Alegre: EMATER/RS. 2008. 222p. 


\section{Main author biography}

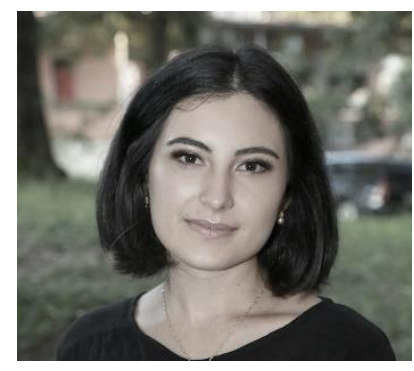

Geise Macedo dos Santos, born in Anita Garibaldi, SC. Graduated in Civil Engineering at Caxias do Sul University - Caxias do Sul, RS. Worked as scientific initiation scholarship holder in geoprocessing and remote sensing from 2014 to 2017. The works carried out since that period involved the northeast region of Rio Grande do Sul State, with the production of cartographic materials. Currently, master's student of the Postgraduate Program in Engineering and Environmental Sciences at the University of Caxias do Sul and member of the technical staff of the Institute of Environmental Sanitation at the University of Caxias do Sul, RS. 